\title{
ПОШИРЕННЯ ТРЕМАТОДОЗІВ ВЕЛИКОЇ РОГАТОЇ ХУДОБИ ТА ЗАХОДИ БОРОТЬБИ
}

\author{
Ю. Довгій, А. Гудь
}

Поліський національний університет

Науковим дослідженням було установлено, щзо в господарствах Житомирської області, широке розповсюдження набули такі паразитарні захворювання: фасиіольоз, парамфістоматоз та дикроцеліоз. Вони є досить почиреними на даній території і несуть значні економічні збитки для господарств.

Досліджено, щуо середня екстенсивність інвазії становила 38,2\%, парамфістомозу 4,2\% та дикрочеліозу 6,9\%, при максимальній ураженості в даному господарстві складає в межах 33$42 \%$. Встановлено, щуо шляхами розповсюдження даних захворювань є стоячі мілкі водоймища, щуо знаходяться на пасовищах де випасається велика рогата худоба. Упродовж весняного періоду трематодозна інвазія почала знижуватись $і$ зберігалась на такому рівні влітку та восени.

Результати досліджень свідчили про зміни гематологічних показників крові у хворих тварин після введення антигельмінтика «Тектін Супер». На початку досліджень було встановлено, щуо у хворих тварин інтенсивність інвазї складала 12,0 яєць фасиіол, 7,0 яєць дикрочелій, 4,0 яйия парамфістом в одному грамі фекалій. На 15 - добу ефективність антигельмінтика становила 100\%. Було отримано задовільні результати після лікування, щьо підтверджується підвищенням кількості еритроцитів, сегментоядерних нейтрофілів, лімфоцитів, вмісту гемоглобіну в еритроциті, гематокриту. Гематологічні показники крові тварин відновились до фізіологічних меж.

Підвищення біохімічних показників крові до фізіологічних меж або контрольної групи, проходило за рахунок дії антигельмінтика Тектін Супер на фасціоли, дикроиелії, парамфістоми. Це проходило за рахунок припинення синтезу $i$ проникнення в організм продуктів життєдіяльності трематод, що володіє імуносупресивною дією. Результат діі антигельмінтика на організм був позитивним.

Ключові слова: яйця, кров, трематоди, Тектін Супер, інтенсивність інвазї.

Постановка проблеми. Трематодози є одними з найбільш широко розповсюджених та небезпечних гельмінтозів, які спричиняють різке зниження молочної та м'ясної продуктивності тваринництва [1, с. 7].

Серед гельмінтозів жуйних тварин, які завдають значних економічних збитків в усіх країнах світу і гальмують розвиток тваринництва, фасціольоз, парамфістоматоз та дикроцеліоз $є$ найбільш розповсюдженими. За літературними джерелами цей гельмінтоз, як правило реєструється на всіх континентах земної кулі у вигляді епізоотій у Європі. Екстенсивність інвазії в середньому складає від 26,2 до 78,3\% при максимальній інтенсивності інвазії 52,3 фасціол на тварину [2, с. 16].

Вперше фасціольозна інвазія згадується у літературних джерелах близько 600 років назад. Про це свідчить інформація датована 1379 роком автором Жаном де Брі, він завідував вівцефермами при Карлі V. Він писав, що фасціольоз «Хвороба, яку називають плоским глистом, з'являється в овець, які вживають траву, що росте на болотистих місцях і має назву “пекучий жовтець”. Це трава (“пекучий жовтець”), що приростає до печінки тварин, є дуже небезпечною і завдає значних збитків» [3, с. 1611].

У деяких регіонах летальність серед уражених овець досягає 14-26\%. У Бразилії F.hepatica реєструється серед 65\% великої рогатої худоби й овець, на Кубі - 40,0\%. Особливо масові прояви трематодозів мають місце в Нігерії, Уругваї, Перу, Чилі, Мексиці де екстенсивність інвазії в середньому складає 27,2-35,3\% [4, с. 139].

Максимальний прояв фасціольозу у Білорусі спостерігається із серпня по грудень - січень, a ранні спалахи захворювання зумовлені наявністю збудників інвазії в молюсках які перезимували. Інвазованість тварин фасціолами у перші дні пасовищного періоду в умовах Білорусі становила 6,5-8,2\% [5, с. 234]. Характеризуючи природно-кліматичні умови, що використовуються під пасовища значних масивів низинних і заболочених земель, де мешкають 
прісноводні молюски - проміжні трематод, сприяли широкому розповсюдженню ряду гельмінтозів сільськогосподарських тварин, особливо фасціольозу, парамфістоматозу [6, с. 3]. Збільшення кількості уражених трематодозами тварин на одиниці площі пасовища призводить до більшого виділення яєць гельмінтами та інтенсивного розвитку епізоотичного процесу [7, с. 557]. Подальший розвиток епізоотичного процесу відбувається на пасовищі. До «факторів пасовища» належать різноманітні кількісні та якісні зміни в різних екологічних умовах, які регулюють «фактор молюска» і «фактор адолескарія» [8, с. 6]. При випасанні невеликої кількості тварин на певній території компоненти біоценозу перебувають у стані постійної взаємодії та рівноваги. У той же час велика кількість тварин уражених трематодами зумовлювали виникнення спалахів фасціольозу та дикроцеліозу [9, с. 35].

В Україні проблему трематодозної інвазії більше розпочали вивчати приблизно з 1950 року на території західних областей, адже вони найбільше потерпали від даної інвазії. Багато українських вчених присвятили свої праці трематодозам. Серед них В.І. Здун, М.Д. Кльосов, А.Й. Меремінський, І.С. Гончарук, К.П. Корж, В.Ф. Павлов та багато інших. Вони описали флору личинок фасціол в молюсках на території західних областей України. Також було встановлено, що проміжним хазяїном є молюск Galba truncatula, який розповсюджений у Карпатах. [10, с.53].

Аналіз актуальних досліджень. Таким чином, аналіз стану вивчення фасціольозної інвазії жуйних тварин на території України, показує що ця проблема вирішувалась головним чином в західних областях України [11, с. 123]. Практично достатньо проводилися дослідження в умовах Півдня України, де ведення тваринництва відрізняється від технології Центрального Полісся України. Проте такі дані відсутні щодо зони Центрального Полісся України, особливо Житомирської області, де ведення тваринництва відрізняється від західних областей України, а природно-кліматичні умови мають певні особливості. Повідомлення з цих питань у доступній літературі відсутні. Боротьба 3 трематодозами в більшості господарств зводиться іноді до планової дегельмінтизації. Враховуючи те, що ситуація з трематодозною інвазією є досить таки напруженою в Україні, та як описували вище. Виходячи 3 цього є потрібним досконаліше вивчення цієї проблеми глибше. Адже $є$ необхідним $є$ пізнання поширення та патогенетичного впливу збудника на організм тварин, удосконалення методів прижиттєвої діагностики трематодозів. Також важливим моментом у боротьбі зі збудником $є$ розроблення новітніх ефективних методів та заходів. Ця проблема $\epsilon$ і лишається актуальною для вивченням, тому що носить значуще народно-господарське значення. Актуальним для практикуючих лікарів ветеринарної медицини $€$ вивчення новітніх антигельмінтних препаратів при боротьбі зі змішаним або асоціативним перебігом гельмінтної інвазії великої рогатої худоби. Доцільним $\epsilon$ впровадження та дослідження антигельмінтних препаратів, які мають широкий спектр дії на збудники, та їх вплив на імунологічні та гематологічні показники крові ВРX [12, с. 13].

Значну частину паразитарних захворювань якими хворіють жуйні тварини складають трематодози. Вони сповільнюють розвиток тваринництва у всьому світі. Фасціольоз великої рогатої худоби є одним з найбільш розповсюдженим серед них і поширений практично на всій земній кулі. Аналізуючи літературні джерела можна зробити висновок, що дана гельмінтологічна хвороба зачасту проявляється у вигляді епізоотій на Європейському континенті ( Велика Британія, Іспанія, Португалія та Австрія) також є чимала кількість випадків в Північній, Південній та Центральній Америці. Фасціольоз набирає все більших обертів [13, с. 361].

Ефективними антигельмінтиками при фасціольозі i дикроцеліозі жуйних тварин $\epsilon$ альбендазол. Препарат призначений внутрішньо в дозах $5 ; 7,5 ; 10 \mathrm{Mг} / к г$, забезпечував $100 \%$ ефективність при фасціольозі, а в дозах 10, 20, 30мг/кг - при дикроцеліозі [14, с. 44]. Лікарські форми альбендазолу (вермітан, атозол, бровальзен) забезпечували 100\% ефективність при фасціольозі та дикроцеліозі у дозах відповідно 7,5 і 70мг/кг [15, с. 48].

Отже, важливим у вирішенні проблеми профілактики і боротьби з трематодозами є вивчення механізму імунітету [16, с. 10]. Досягнення останніх років у галузі імунофармакології дозволяє вирішувати проблеми імуностимуляції [17, с. 370]. Інтенсивне відновлення імунобіологічних показників дослідних тварин спостерігалося після лікування більш при гострому фасціольозі ніж за хронічної форми [18, с. 310].

Успіх лікування та профілактики гельмінтозів у тварин залежить від захисних сил організму, тому що гельмінти викликають вторинні імунодефіцити [19, с. 288]. Аналізуючи 
попередні дослідження на даному етапі розвитку тваринництва, актуальність досліджень, це вивчення новітніх антигельмінтних препаратів, їх вплив на імунний стан тварин та зменшити відсоток хворих тварин на трематодози або повне лікування. Вивчення хвороб різної етіології має велике значення для ведення успішного тваринництва в Україні [20, с. 288]

Дослідження, які були проведені у даному напрямку дадуть змогу розробити науковообгрунтовані та економічно-ефективні заходи боротьби з фасціольозом, парамфістоматозом та дикроцеліозом на території Житомирської області.

Метою даної роботи $є$ встановити розповсюдження, сезонну динаміку, ефективність антигельмінтика «Тектін Супер» та його вплив на гематологічні показники організму хворих тварин при трематодозах.

Виклад основного матеріалу. Вивчили розповсюдження, епізоотологію, ефективність антигельмінтика нового покоління «Тектін Супер» та його вплив на його показники організму хворих корів при трематодозах, вивчали в П(ПО)СП «Світоч» Новоград-Волинського району, Житомирської області.

Аналіз статистичного матеріалу (2016-2021pp.) показав, що в господарствах Житомирської області, фасціольоз, парамфістомоз та дикроцеліоз мав широке розповсюдження. Середня ЕI фасціолами упродовж 5-ти річного спостереження становила 38,2\%, парамфістомозу 4,2\% i дикроцеліозу $6,9 \%$. Максимальна ураженість трематодозами в даному господарстві в середньому складала $33-42 \%$.

Було встановлено, що основною причиною розповсюдження даних захворювань, це наявність стоячих мілких водойм на пасовищах де випасаються тварини (Рис. 1).

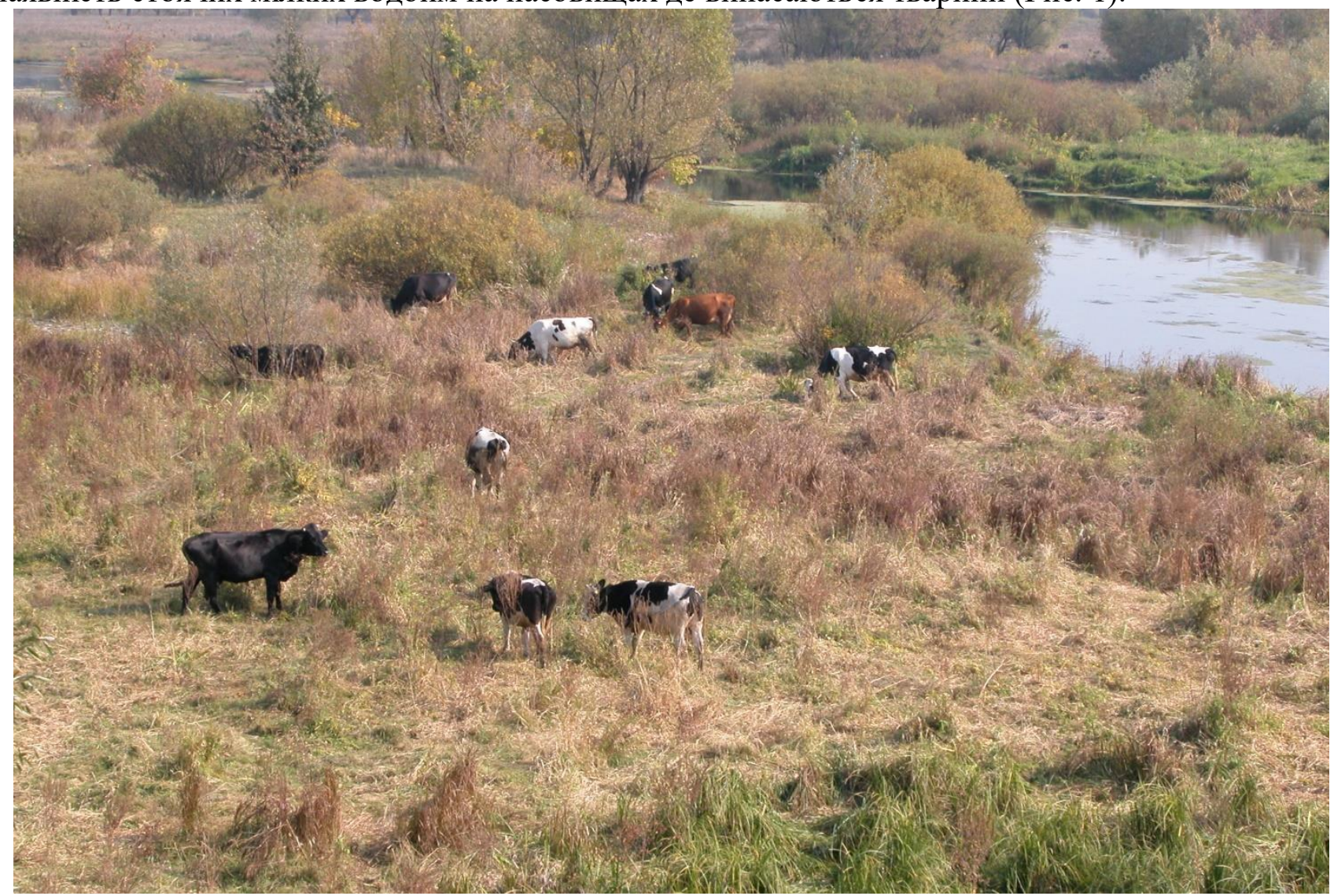

Рис. 1. Біотоп збудників трематодозів

У сезонному аспекті максимальне ураження тварин паразитичними червами спостерігали в

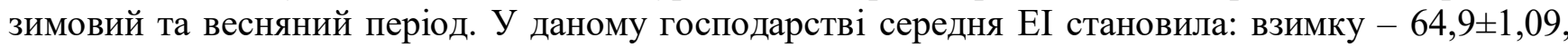
весною - 61,32 $\pm 0,95 \%$ (Рис. 2).

Упродовж весни трематодозна інвазія знижувалась і зберігалась на такому рівні влітку та восени. Така неоднорідна ураженість великої рогатої худоби трематодозами пов'язана 3 використанням для випасання корів перезволожених місць, де створилися оптимальні умови для 
збільшення кількості та розвитку прісноводних молюсків Lymnaea truncatula ( малий ставковик) - проміжних живителів.

Вплив антигельмінтика Тектін Супер на гематологічні показники організму хворих корів на фасціольоз, дикроцеліоз, парамфістоматоз вивчали в П(ПО)СП «Світоч» Новоград-Волинського району Житомирської області.

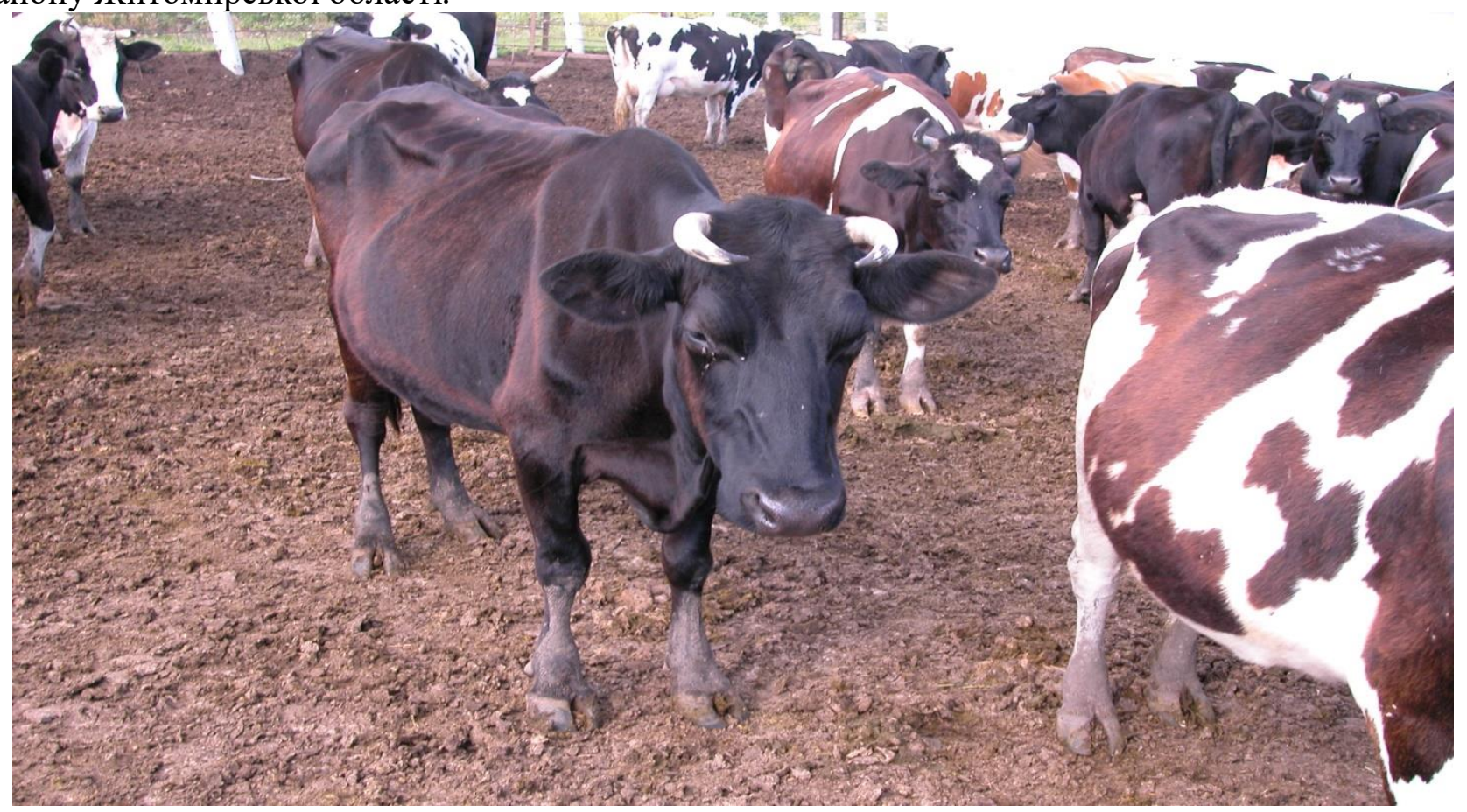

Рис. 2. Велика рогата худоба хвора на трематодозну інвазію.

Ряд досліджень фекалій та крові проводилися із застосуванням сучасних методів у акредитованій Житомирській регіональній державній лабораторії державної служби України 3 питань безпечності та якості харчових продуктів та захисту споживачів. Також деякі дослідження проводились у навчально-науковій клініко-діагностичній лабораторії при Поліському національному університеті.

Антигельмінтик Тектін Супер має діючу речовину івермектин - 10мг та клорсулон - 100мг. Він випускається у вигляді розчину для ін'єкцій. Він добре розприділяється по організму тварини.

Тектін Супер вводили підшкірно в дозі $1 \mathrm{~cm}^{3}$ на 50кг маси тіла тварини, одноразово. Було сформовано групи корів (контрольна) і (дослідна) по 5 голів у кожній, віком 4 роки, чорно-рябої породи, масою тіла 450-500кг. Тваринам, які знаходилися у контрольній групі (здорові тварини) антигельмінтна обробка не проводилася.

Дослідження морфологічних показників крові проводили до застосування препарату, а також через 7,15,30 діб.

Результати досліджень свідчили (табл.1) про зміни морфологічних показників крові тварин після введення їм препарату за інтенсивності інвазії на початку досліджень 12,0 яєць фасціол, 7 яєць дикроцелій, 4 яйця парамфістоми в 1г фекалій.

Через 7 діб після введення хворим тваринам Тектін Супер при інтенсивності інвазії 8 яєць фасціол, 5 дикроцелій, 3 парамфістоми. У морфологічних показниках крові у корів видимих змін не виявлено.

На 15-ту добу, в організмі корів яєць фасціол, дикроцелій, парамфістом не виявлено, де екстенсефективність склала 100\%, Порівняно з вихідними даними кількість еритроцитів, Т/л збільшилась на 15 -ту добу із $8,7 \pm 0,12$ до $9,1 \leq 0,14 \%$ (на $4,4 \%, p \leq 0,05$ ), на 30 -ту добу до $9,7 \pm 0,15 \%$

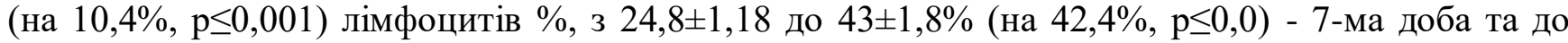
$47,5 \pm 2,1 \%$ (та $47,9 \%, \mathrm{p} \leq 0,01)$ - 30-та доба, середній вміст гемоглобіну в еритроциті пг (МСН) на 15 -ту добу з $11,6 \pm 0,4$ до $13,2 \pm 0,7 \%$ (на $16,3 \%, p \leq 0,001$ ), на 30 -ту добу до $14,1 \pm 0,71 \%$ (на $21,6 \%$,

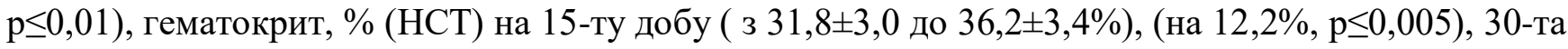
доба до $40,1 \pm 3,9 \%$ (на $20,7 \%, \mathrm{p} \leq 0,001)$. 
Зниження морфологічних показників крові до фізіологічних меж відмічали особливо на 30-

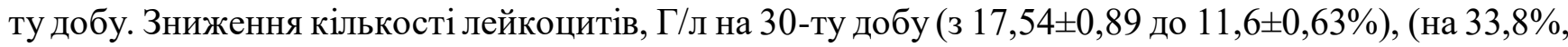
$\mathrm{p} \leq 0,001)$, зниження кількості еозинофілів, $\% \quad(11,2 \pm 0,8$ до $7,2 \pm 0,41 \%)$, (на $35,7 \%, \mathrm{p} \leq 0,01)$,

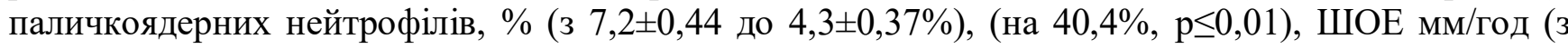
$6,2 \pm 0,11$ до $2,8 \pm 0,7 \%$ ), (на $54,8 \%, \mathrm{p} \leq 0,01$ ).

Результати досліджень показали, що у хворих на фасціольоз, дикроцеліоз, парамфістоматоз тварин зміни еритроцитів, лейкоцитів, еозинофілів, паличкоядерних та сегментоядерних нейтрофілів, лімфоцитів, гемоглобіну, гематокриту і ШОЕ, на 15-ту та 30-ту добу.

Таблиця 1. Зміни морфологічних показників у крові великої рогатої худоби, хворої на фасціольоз, дикроцеліоз, парамфістоматоз при застосуванні Тектін Супер.

\begin{tabular}{|c|c|c|c|c|c|c|}
\hline \multirow{5}{*}{\multicolumn{2}{|c|}{ Показники }} & $\begin{array}{l}\text { Здорові } \\
\text { тварини }\end{array}$ & $\begin{array}{c}\text { На } \\
\text { початку } \\
\text { досліду }\end{array}$ & $\begin{array}{l}\text { Через } 7 \\
\text { діб }\end{array}$ & $\begin{array}{l}\text { Через } 15 \\
\text { діб }\end{array}$ & $\begin{array}{l}\text { Через } 30 \\
\text { діб }\end{array}$ \\
\hline & & \multicolumn{5}{|c|}{ Інтенсивність інвазії яєць фасціол, дикроцелій, парамфістоми } \\
\hline & & \multirow{3}{*}{0} & $\Phi-12$ & $\Phi-8$ & $\Phi-0$ & $\Phi-0$ \\
\hline & & & Д-7 & Д - 5 & Д- 0 & Д - 0 \\
\hline & & & П-4 & $\Pi-3$ & $\Pi-0$ & $\Pi-0$ \\
\hline \multicolumn{2}{|c|}{ Еритроцити, Т/л } & $9,8 \pm 0,15$ & $8,7 \pm 0,12$ & $8,7 \pm 0,12$ & $9,1 \pm 0,14$ & $9,7 \pm 0,15$ \\
\hline \multicolumn{2}{|c|}{ Гемоглобін, г/л } & $10,1 \pm 0,68$ & $17,54 \pm 0,89$ & $16,2 \pm 0,87$ & $13,2 \pm 0,68$ & $11,6 \pm 0,63$ \\
\hline \multicolumn{7}{|c|}{ Лейкограма, \% } \\
\hline \multicolumn{2}{|c|}{ Базофіли } & $1 \pm 0,11$ & $0,2 \pm 0,2$ & $0,2 \pm 0,2$ & $0,2 \pm 0,2$ & $0,2 \pm 0,2$ \\
\hline \multicolumn{2}{|l|}{ Еозинофіли } & $6 \pm 0,3$ & $11,2 \pm 0,8$ & $11,0 \pm 0,7$ & $8,0 \pm 0,4$ & $7,2 \pm 0,41$ \\
\hline \multirow{4}{*}{ Нейтрофіли } & мієлоцити & 0 & 0 & 0 & 0 & 0 \\
\hline & юні & 0 & 0 & 0 & 0 & 0 \\
\hline & паличкоядерні & $4 \pm 0,10$ & $7,2 \pm 0,44$ & $7,0 \pm 0,43$ & $5,0 \pm 0,39$ & $4,3 \pm 0,37$ \\
\hline & сегментоядерні & $32 \pm 1,21$ & $49,8 \pm 1,1$ & $49,0 \pm 0,11$ & $37 \pm 0,91$ & $34 \pm 0,87$ \\
\hline \multicolumn{2}{|l|}{ Лімфоцити } & $60 \pm 1,3$ & $24,8 \pm 1,18$ & $52,6 \pm 1,16$ & $43 \pm 1,8$ & $47,5 \pm 2,1$ \\
\hline \multicolumn{2}{|c|}{ Моноцити } & $7 \pm 0,4$ & $6,8 \pm 0,3$ & $7,2 \pm 0,4$ & $6,8 \pm 0,38$ & $6,8 \pm 0,38$ \\
\hline \multicolumn{2}{|c|}{$\begin{array}{l}\text { Середній вміст гемоглобіна в } \\
\text { еритроциті, пг (МСН) }\end{array}$} & $14,4 \pm 0,72$ & $11,06 \pm 0,4$ & $11,06 \pm 0,4$ & $13,2 \pm 0,7$ & $14,1 \pm 0,71$ \\
\hline \multicolumn{2}{|c|}{ Гематокрит, \% (НСТ) } & $41,0 \pm 3,6$ & $31,8 \pm 3,0$ & $35,8 \pm 3,1$ & $36,2 \pm 3,4$ & $40,1 \pm 3,8$ \\
\hline \multicolumn{2}{|c|}{ ШОЕ (мм/год) } & $2,9 \pm 0,8$ & $6,2 \pm 0,11$ & $5,2 \pm 0,9$ & $3,0 \pm 0,7$ & $2,8 \pm 0,7$ \\
\hline
\end{tabular}

Примітка: $\mathrm{xp} \leq 0,05 ; \mathrm{xxp} \leq 0,01 ; \mathrm{xxx} \leq 0,001$;

Отже, підвищення кількості еритроцитів, сегментоядерних нейтрофілів, лімфоцитів та вмісту гемоглобіну в еритроциті, гематокриту та відновлення до фізіологічної межі та кількості лейкоцитів, еозинофілів, паличкоядерних нейтрофілів, ШОЕ, пов'язане 3 дією препарату на фасціоли, дикроцелії, парамфістоми і припинення синтезу та проникнення їх токсину в організм, який володіє імуносупресивною дією.

На нашу думку, механізм дії Тектін Супер полягає у зменшенні та зниженні токсичного впливу фасціол, дикроцелій, парамфістом, оскільки ЕЕ та IЕ цього препарату склала 100\%.

Збільшення деяких біохімічних показників у крові хворих корів на трематодози в порівнянні до вихідних даних і відновлення їх до показників контрольної групи (здорові тварини) особливо на 15-ту та 30-ту добу.

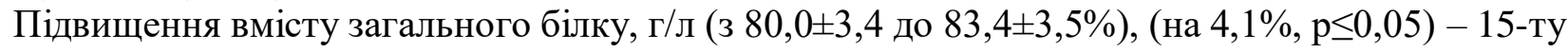

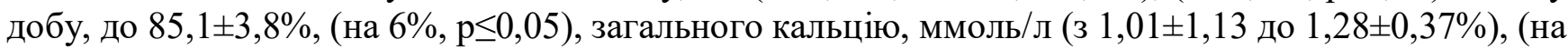
$21,1 \%, \mathrm{p} \leq 0,001), 15$-ту добу, до $1,74 \pm 0,15 \%$ (41,9\%, $\leq \leq 0,01), 30$-та доба, фосфору, ммоль/л (з $0,50 \pm 0,1$ до $0,93 \pm 0,3 \%$ ), (на 46,3\%, p $\leq 0,01), 15$-та доба, до $1,8 \pm 0,01 \%$ (на 76,3\%, $\leq 0,01$ ), каротину, мг\% (з $0,280 \pm 0,043$ до $0,385 \pm 0,049 \%),($ на $27,2 \%, \mathrm{p} \leq 0,001)-15$-ту добу, до $0,430 \pm 0,055 \%$, (на

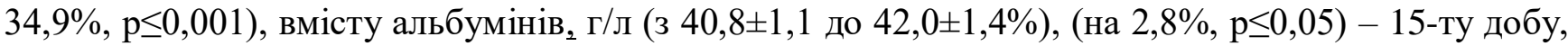

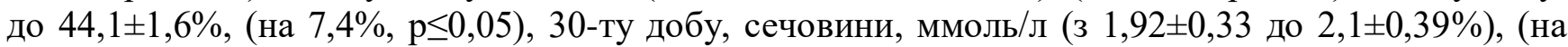

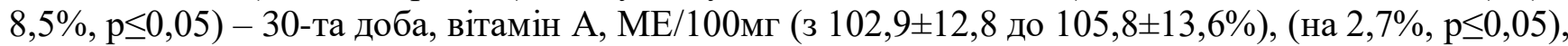

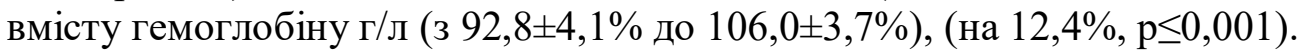


Відмічали зниження до показників контрольної групи, які знаходилися у фізіологічних межах такі показники, як глюкоза і холестерин. Підвищення біохімічних показників до фізіологічних меж або контрольної групи, проходило за рахунок дії Тектін Супер на фасціоли, дикроцелії, парамфістоми та припинення синтезу i проникнення в організм продуктів життєдіяльності трематод, що володіють імуносупресивною дією.

Таблиця 2. Зміни біохімічних показників крові у великої рогатої худоби, хворої на фасціольоз, дикроцеліоз, парамфістоматоз при застосуванні Тектін-Супер.

\begin{tabular}{|c|c|c|c|c|c|}
\hline \multirow{3}{*}{ Показники } & $\begin{array}{l}\text { Здорові } \\
\text { тварини }\end{array}$ & $\begin{array}{c}\text { На початку } \\
\text { досліду }\end{array}$ & Через 7 діб & Через 15 діб & Через 30 діб \\
\hline & \multicolumn{5}{|c|}{ Інтенсивність інвазії яєць фасціол, дикроцелій, парамфістоми } \\
\hline & 0 & $\begin{array}{c}\text { Ф-12 } \\
\text { Д-7 } \\
\Pi-4\end{array}$ & $\begin{array}{c}\text { Ф-8 } \\
\text { Д-5 } \\
\Pi-3\end{array}$ & $\begin{array}{l}\text { Ф-0 } \\
\text { Д-0 } \\
\Pi-0\end{array}$ & $\begin{array}{c}\Phi-0 \\
\text { Д - } 0 \\
\Pi-0\end{array}$ \\
\hline $\begin{array}{l}\text { Загальний } \\
\text { білок, г/л }\end{array}$ & $85,2 \pm 3,8$ & $80,0 \pm 3,4$ & $78,0 \pm 2,85$ & $83,4 \pm 3,5$ & $85,1 \pm 3,8$ \\
\hline $\begin{array}{l}\text { Загальний } \\
\text { кальцій, } \\
\text { ммоль/л }\end{array}$ & $1,78 \pm 0,11$ & $1,01 \pm 0,13$ & $1,03 \pm 0,13$ & $1,28 \pm 0,17$ & $1,74 \pm 0,15$ \\
\hline $\begin{array}{l}\text { Фосфор, } \\
\text { ммоль/л }\end{array}$ & $1,85 \pm 0,1$ & $0,50 \pm 0,1$ & $0,55 \pm 0,2$ & $0,93 \pm 0,3$ & $1,8 \pm 0,01$ \\
\hline Каротин, мг/\% & $0,455 \pm 0,057$ & $0,280 \pm 0,043$ & $0,301 \pm 0,047$ & $0,385 \pm 0,049$ & $0,450 \pm 0,055$ \\
\hline $\begin{array}{l}\text { Лужний } \\
\text { резерв, } \\
\text { об.\% } \% \mathrm{CO}_{2} \\
\end{array}$ & $49,8 \pm 1,4$ & $47,5 \pm 1,1$ & $47,6 \pm 1,1$ & $47,8 \pm 1,1$ & $43,2 \pm 1,44$ \\
\hline $\begin{array}{l}\text { Альбуміни, } \\
\text { г/л }\end{array}$ & $44,2 \pm 0,9$ & $40,8 \pm 1,1$ & $41,6 \pm 1,2$ & $42,0 \pm 1,4$ & $44,1 \pm 1,6$ \\
\hline $\begin{array}{l}\text { Глюкоза, } \\
\text { ммоль/л }\end{array}$ & $1,236 \pm 0,103$ & $1,17 \pm 0,27$ & $1,19 \pm 0,28$ & $1,21 \pm 0,29$ & $1,24 \pm 0,31$ \\
\hline $\begin{array}{l}\text { Холестерин, } \\
\text { г/л }\end{array}$ & $2,164 \pm 0,262$ & $3,09 \pm 0,120$ & $3,06 \pm 0,122$ & $2,86 \pm 0,104$ & $2,1 \pm 0,192$ \\
\hline $\begin{array}{l}\text { Сечовина, } \\
\text { ммоль/л }\end{array}$ & $2,122 \pm 0,252$ & $1,92 \pm 0,33$ & $1,86 \pm 0,31$ & $1,98 \pm 0,35$ & $2,1 \pm 0,39$ \\
\hline $\begin{array}{l}\text { Вітамін A, ME } \\
(100 \mathrm{Mr})\end{array}$ & $106,6 \pm 8,4$ & $102,9 \pm 12,8$ & $102,1 \pm 12,7$ & $104,4 \pm 13,4$ & $105,8 \pm 13,6$ \\
\hline $\begin{array}{l}\text { Гемоглобін, } \\
\text { г/л }\end{array}$ & $106,0 \pm 3,7$ & $92,8 \pm 4,1$ & $103 \pm 4,2$ & $105,0 \pm 4,3$ & $106 \pm 3,7$ \\
\hline
\end{tabular}

Примітка: $\mathrm{xp} \leq 0,05 ; \mathrm{xxp} \leq 0,01 ; \mathrm{xxx} \leq 0,001$;

За результатами досліджень нами виявлено, що ефективність даного антигельмінтика складає 100\%, і підвищення біохімічних показників більш вірогідними було на 30-ту добу.

На 30-ту добу після дегельмінтизації тварин при проведенні копроовоскопічних досліджень яєць фасціол, парамфістом та дикроцелій не виявлено.

\section{Висновки.}

1. За допомогою копроовоскопічних досліджень встановлено, що трематодози мали виражену сезонну динаміку з максимальним проявом у зимово-весняний період, де пік інвазії припадав на середину грудня до середини березня. Інтенсивність зараження тварин в сезонному аспекті зростала влітку. Це відбувалося внаслідок того, що тварини споживали траву де були адолескарії, які з’явилися від прісноводних молюсків, що перезимували.

2. Ефективність антигельмінтика «Тектін Супер» склала 100\%. Підвищення гематологічних показників були більш вірогідними на 30 -ту добу після лікування, за рахунок пригнічення синтезу і проникнення в організм продуктів життєдіяльності трематод, що володіють імуносупресивною дією. 
Перспективи подальших досліджень. Вивчення інших новітніх антигельмінтиків та їх вплив на імунний стан тварин. Удосконалення методів та методик боротьби з трематодозною інвазією на території центральної зони Полісся України. Проблема трематодозної інвазії є досить актуальною для спеціалістів ветеринарної медицини, тому потрібно вивчати застосування новітніх антигельмінтних препаратів за гострого та хронічного перебігу хвороби.

\section{Список використаних джерел}

1. Довгій Ю. Ю. Фасціольоз великої рогатої худоби в умовах тривалого впливу іонізуючого випромінювання (епізоотологія, патогенез та лікування): дис. ... д-ра вет. наук : спец. 16.00.11 /НАУ. Київ, 2005. 340 с.

2. Study on Prevalence of Fascioliasis in Ruminants in Dasht Room County in Spring and Summer of 2013 / M. Abdolali et al. Animal and Veterinary Sciences. 2016. Vol. 4, N 2. P. 15-18. DOI: 10.11648/j.avs.20160402.11

3. Mortensen R. F., Duszkiewicz J. A. Mediation of CRP-dependent phagocytosis through mouse macrophage Fc-receptors. J. Immunol. 1977. Vol. 119, № 5. P. 1611-1616.

4. Adediran O. A., Adebiyi A. I., Uwalaka E. C. Prevalence of Fasciola species in ruminants under extensive management system in Ibadan southwestern Nigeria. African journal of medicine and medical sciences. 2014. Vol. 43. P. 137-141.

5. Паразитоценозы крупного рогатого скота и меры борьбы с ними / А. И. Ятусевич, Е. Л. Братушкина, Р. Н. Протасовицкая, В. П. Пивовар. Наук. вісник наи. аграрного університету. 2006. Вип. 98. С. 233-236.

6. Шевченко А. М. Парамфістоматидози жуйних тварин (епізоотологія, діагностика, лікування і профілактика) : автореф. дис. на здобуття наук. ступеня канд. вет. наук. Київ, 2006. 21 c.

7. Ahmadi-hamedani M. Evaluation of selected biochemical parameters and hepatic enzymes activity in serum of cattle naturally infected with Dicrocoelium dendriticum in Semnan Province, Iran. Comparative Clinical Pathology. 2016. N 3. P. 555-558. https://doi.org/10.1007/s00580-016-2227-z

8. Alzaheb R. A., Al-Amer O. The Prevalence of Iron Deficiency Anemia and its Associated Risk Factors Among a Sample of Female University Students in Tabuk, Saudi Arabia. Clinical Medicine Insights: Women's Health. 2017.Vol. 10. P. 1-8. http://dx.doi.org/10.1177/1179562X17745088

9. Fasciola hepatica: A comparative survey of adult fluke resistance to triclabendazole, nitroxynil and closantel on selected upland and lowland sheep farms in Northern Ireland using faecal egg counting, coproantigen ELISA testing and fluke histology / Hanna R. E. B., McMahon C., Ellison S., Edgar H. W., Kajugu P. E., Gordon A. et al. Veterinary Parasitology. 2015. Vol. 207, N 1/2. P. 34-43. https://doi.org/10.1016/j.vetpar.2014.11.016

10. Здун В. И., Яворский И. П. Профилактика фасциолеза в Предкарпатье и на сопредельных территориях. Методы профилактики и борьбы с трематодозами человека $u$ животных : тез. докл. Всесоюз. науч. конф. (г. Сумы, 9-11 октября 1991 г.). Москва, 1991. С. $53-$ 54.

11. Куляба О. В., Стибель В. В., Гутий Б. В. Вплив клозаверму А та катозалу на показники протеїнсинтезувальної функції печінки корів за експериментального фасціольозу, сенсибілізованих атиповими мікобактеріями. Наук. вісник Львів. Наи. університету вет. медицини та біотехнологій ім. С. 3. Гжицького. 2017. Т. 17, вип. 73. С. 122-125. DOI: $10.15421 /$ nvlvet 7325

12. Білопольська Т. П. Дикроцеліоз великої рогатої худоби в умовах Півдня України (поширення, діагностика, лікування) : автореф. дис. на здобуття наук. ступеня канд. вет. наук. Київ, 2012. 21 с.

13. Boray J. C. Fortshritte in der Bekampfung der Fasciolose. Schweizer. Arch. Tierheilkunde. 1971. Vol. 113, № 7. Р. 361-386.

14. Березовський А. В. Лікарські препарати нового покоління для ветеринарної медицини. Київ : Ветінформ, 2000. 88 с.

15. Довгій Ю. Ю. Трематодози жуйних тварин в забрудненій радіонуклідами та умовно чистій зонах : монографія. Київ : Видав. центр НАУ, 2008. 114 с. 
16. Fasciola hepatica is associated with failure to detect bovine tuberculosis in dairy cattle / Claridge J., Diggle P., McCann C. M., Mulcahy G., Flynn R., McNair J. et al. Nat Commun. 2012. N 3. P. 853. DOI: $10.1038 /$ ncomms 1840

17. Brygadyrenko V., Ivanyshyn V. Changes in the body mass of Megaphyllum kievense (Diplopoda, Julidae) and the granulometric composition of leaf litter subject to different concentrations of copper. Journal of Forest Science. 2015. Vol. 61, N 9. P. 369-376. http://dx.doi.org/10.17221/36/2015-JFS

18. Mapping human health risks from exposure to trace metal contamination of drinking water sources in Pakistan / Bhowmik A. K., Alamdar A., Katsoyiannis I., Shen H., Ali N., Alie S. M. et al. Science of The Total Environment. 2015. Vol. 538. P. 306-316. http://dx.doi.org/10.1016/j.scitotenv

19. Chronic arsenicosis in cattle with special reference to its metabolism in arsenic endemic village of Nadia district West Bengal In Mishra / Datta B. K., Mishra A., Singh A., Sar T. K., Sarkar S., Bhatacharya A. et al. Science of The Total Environment. 2010. Vol. 409, N 2. P. 284-288. http://dx.doi.org/10.1016/j.scitotenv.2010.10.003

20. Experimental study of tropism in cultivated canine coronavirus in the small intestine of puppies / Goralskii L., Radzikhovsky N., Dyshkant O., Dunaievska O., Sokulskiy I. Regulatory Mechanisms in Biosystems. 2019. Vol. 10, № 4. P. 489-496. https://doi.org/10.15421/021972

\section{РАСПРОСТРАНЕНИЕ ТРЕМАТОДОЗОВ КРУПНОГО РОГАТОГО СКОТА И МЕРЫ БОРЬБЫ}

Довгий Ю., Гудь А.

Научными исследованиями было установлено, что в хозяйствах Житомирской области, широкое распространение получили такие паразитарные заболевания: фасииолез, парамфистоматоз и дикрочелиоз. Они являются довольно распространенными на данной территории и несут значительные экономические убытки хозяйствам.

Доказано, что средняя экстенсивность инвазии составила 38,2\%, парамфистомоза 4,2\% и дикрочелиоза 6,9\%, при максимальной пораженности в данном хозяйстве составляет около 33 42\%. Установлено, что путями распространения данных заболеваний являются стоячие мелкие водоемы, которые находятся на пастбищах, где пасется крупный рогатый скот. В течение весеннего периода трематодозная инвазия начала снижаться и сохранялась на таком уровне летом и осенью.

Результаты исследований свидетельствовали об изменениях гематологических показателей крови у больных животных после введения антигельминтика «Тектин Супер». $B$ начале исследований было установлено, что у больных животных интенсивность инвазии составляла 12,0 яиц фасииол, 7,0 яиц дикрочелий, 4,0 яйца парамфистом в одном грамме фекалий. На 15-сутки эффективность антигельминтика составляла 100\%. Было получено удовлетворительные результаты после лечения, что подтверждается увеличением количества эритрочитов, сегментоядерных нейтрофилов, лимфоцитов, содержания гемоглобина в эритроците, гематокрита. Гематологические показатели крови животных возобновились $к$ физиологической границе.

Повышение биохимических показателей крови к физиологической границе или контрольной группь, проходило за счет действия антигельминтика Тектин Супер на фасциоль, дикроцелии, парамфистомы. Это проходило за счет прекращения синтеза и проникновение в организм продуктов жизнедеятельности трематод, обладающий иммуносупрессивным действием. Результат действия антигельминтика на организм был положительным.

Ключевые слова: яйца, кровь, трематоды, Тектин Супер, интенсивность инвазии.

\section{CATTLE TREMATODES SPREADING AND DISHELMINTHIZATION}

Dovhiy U., Hud A.

The scientific investigation has established that such diseases as fascioliasis, paramphistomatosis, dicroceliosis are widely spread on the livestock farms of Zhytomyr oblast. They are widely spread on this territory and cause heavy losses for the farm owners.

It has been established that an average invasion extensity equalled $38.2 \%$, that of paramphistomatosis equalled $4.2 \%$ and that of dicroceliosis equalled $6.9 \%$, under a maximal prevalence 
on a given livestock farm within 33-42\%. It has been also established that shallow bodies of water, which are on the pasture areas, where the cattle graze is the way of spreading the disease. During a spring period trematodes invasion started decreasing and was on the same level in summer and in autumn.

The investigation results testified to some changes in haematology parameters in sick animals after introducing anthelmintic "Tektin Super". At the beginning of the investigation it was detected that the invasion intensity in sick animals amounted 12.0 fasciola eggs, 7.0 dicrocela eggs, 4.0 paramphistoma eggs per $1 \mathrm{gr}$ of faeces. On the $15^{\text {th }}$ day the anthelmintic effectiveness equalled 100\%. Positive results of treatment were confirmed by an increase in the amount of red blood cells, polymorpho-nuclear leucocytes, white blood cells, content of hemoglobulin in red blood cells, hematocrit. Haematology indices of animals blood were renewed within their physiological parameters.

The increase in biochemical parameters of blood to physiological limits, or to that of a control group, was due to the effects of anthelmintic "Tektin Super" on fasciola, dicrocela and paramphistoma. It occurred as a result of synthesis subsidence and due to the penetration of trematoda waste products (which have immuno-suppressive action) into the body. Anthelmintic had positive effects on the organism.

Key words: eggs, blood, trematoda, "Tektin Super", invasion intensity. 